\title{
Hubungan obesitas pada kehamilan dengan preeklampsia
}

\author{
${ }^{1}$ Caroline E. G Dumais \\ ${ }^{2}$ Rudy A. Lengkong \\ ${ }^{2}$ Maya E. Mewengkang
}

\author{
${ }^{1}$ Kandidat Skripsi Fakultas Kedokteran Universitas Sam Ratulangi Manado \\ ${ }^{2}$ Bagian Obstetri dan Ginekologi Fakultas KedokteranUniversitas Sam Ratulangi - \\ RSUP Prof. dr. R. D. Kandou Manado \\ Email: dumaiscaroline@yahoo.com
}

\begin{abstract}
This study aimed to obtain the relationship between obesity in pregnancy and preeclampsia. This was a retrospective analytical study with a case-control design by using data of patients' medical records. Samples were pregnant women with obesity (IMT $\geq 30$ $\mathrm{kg} / \mathrm{m}^{2}$ ) at the last pregnancy that suffered from preeclampsia and obese pregnant women without preeclampsia at RSUP Prof. Dr. R. D. Kandou Manado from January, 2013 until December 2014. Data were processed by using SPSS 2.0. The results showed that the number of obese pregnant women that suffered from preeclampsia and obese pregnant women without preeclampsia was 60 people. Most of them suffered from preeclampsia were categorized as obesity I. The chi-square test showed a p value $=0.013(<\alpha=0.05)$. Conclusion: There was a relationship between obesity at pregnancy with preeclampsia at pregnant women at RSUP Prof. Dr. R. D. Kandou Manado.
\end{abstract}

Keywords: BMI, obesity, preeclampsia

\begin{abstract}
Abstrak: Penelitian ini bertujuan untuk mengetahui hubungan obesitas pada kehamilan dengan pre-eklampsia. Jenis pnelitian ini analitik retrospektif dengan desain case-control. Data penelitian diperoleh dari catatan rekam medis pasien. Sampel penelitian ini ialah wanita hamil dengan obesitas (IMT $\geq 30 \mathrm{~kg} / \mathrm{m}^{2}$ ) pada akhir kehamilan yang menderita pre-eklampsia dan wanita hamil obes tanpa pre-eklampsia di RSUP Prof. Dr. R.D. Kandou Manado dari bulan Januari 2013 sampai Desember 2014. Data yang diperoleh diolah dengan menggunakan SPSS 2.0. Hasil penelitian memperlihatkan bahwa jumlah wanita hamil dengan obesitas yang menderita pre-eklampsia dan wanita obes tanpa pre-eklampsia sebanyak 60 orang. Sebagian besar responden dengan pre-eklampsia termasuk obesitas I. Hasil uji chi square dengan tingkat signifikan $\alpha=0,05$ mendapatkan nilai $p=0,013(<\alpha=0,05)$. Simpulan: Terdapat hubungan antara obesitas pada kehamilan dengan pre-eklampsi pada wanita hamil di RSUP Prof. Dr. R. D. Kandou Manado
\end{abstract}

Kata kunci: IMT, obesitas, pre-eklampsia

Pre-eklampsia diperkirakan sebagai penyebab kematian 50.000-60.000 ibu hamil setiap tahunnya. Pre-eklampsia diketahui merupakan kontributor utama prematuretas. ${ }^{1}$ Pre-eklampsia merupakan sebuah sindrom sistemik dalam kehamilan yang bermula dari plasenta akibat dari invasi sitotrofoblas plasenta yang inadekuat diikuti dengan disfungsi endotel maternal yang meluas. ${ }^{2}$ Semua gejala klinis preeklampsia disebabkan oleh endoteliosis glomerulus, peningkatan permeabilitas vaskular, dan respon inflamasi sistemik yang menyebabkan jejas dan/atau hipoperfusi pada organ. ${ }^{3}$

Pada tubuh perempuan hamil dengan pre-eklampsia terjadi beberapa perubahan patofisiologis pada beberapa organ /siystem 
organ yang akan bermanifestasi pada tampilan klinis. Perubahan-perubahan ini diperkirakan akibat vasopasme, disfungsi endotel, dan iskemia yang terjadi. Diagnosis dari pre-eklampsia berdasarkan tekanan darah dan proteinuria.,

Pre-eklampsia merupakan masalah kesehatan yang terjadi setelah 20 minggu kehamilan yang ditandai dengan adanya hipertensi dan proteinuria. ${ }^{6}$ Pre-Eklampsia diperkirakan terjadi pada 5\% kehamilan. Pre-eklampsia kemudian dapat berkembang menjadi eklampsia yang dapat menyebabkan kematian maternal dan janin. Pada negara sedang berkembang kejadian eklampsia dilaporkan berkisar antara 0,3\% sampai $0,7 \%$, sedang di negara-negara maju angka kejadian diketahui lebih kecil, yaitu $0,05 \%$ sampai $0,1 \%$. Berdasarkan Depkes RI 2005, dilaporkan bahwa 50.000 ibu meninggal dunia karena Pre-eklampsia dan eklampsia. Insiden Pre-eklampsia dan Pre-eklampsia berat (PEB) berkisar antara 1:1000 sampai $1: 1700 .^{7,8}$

Overweight dan obesitas merupakan risiko terbesar kelima yang dapat menyebabkan kematian global. Suatu penelitian oleh Anjel di Amerika Serikat pada wanita usia subur menunjukkan bahwa 24,5\% wanita usia 20-44 tahun memiliki status gizi overweight dan 23\% di antaranya obesitas. ${ }^{9,10}$

Penelitian yang dilakukan oleh James et al. ${ }^{13}$ menyatakan bahwa berat badan berlebihan pada wanita hamil berhubungan dengan pre-eklampsia. Pada penelitian yang dilakukan Mark et al. ${ }^{14}$ dilaporkan bahwa obesitas pada kehamilan berhubungan dengan peningkatan morbiditas pada ibu dan bayi.

\section{METODE PENELITIAN}

Jenis penelitian ini analitik-retrospektif dengan desain case-control. Penelitian ini bertujuan untuk mengetahui hubungan obesitas pada kehamilan dan pre-eklampsia dengan menggunakan data Rekam Medik. Penelitian ini dilakukan di Bagian/SMF Obstetri Ginekologi di RSUP Prof.dr.R. D.Kandou Manado pada bulan Oktober Desember 2015.
Populasi penelitian ini ialah wanita hamil berusia 20-40 tahun yang menjadi pasien di RSUP Prof.dr. R. D. Kandou Manado. Sampel dihitung dengan menggunakan rumus case control berpasangan dan didapatkan jumlah sampel 39 untuk kelompok kasus dan 21 untuk kelompok kontrol. Kelompok kasus ialah wanita hamil obesitas yang didiagnosis dengan preeklampsia. Kelompok kontrol ialah wanita hamil obesitas tanpa preeklampsia.

Pada penelitian ini indeks massa tubuh (IMT) ibu dibagi menjadi dua kelompok obesitas yaitu Obesitas I (IMT 30-34,9 $\mathrm{kg} / \mathrm{m}^{2}$ ) dan Obesitas II (IMT 35-39.9 $\left.\mathrm{kg} / \mathrm{m}^{2}\right)$.

Data yang diperoleh kemudian diproses dengan menggunakan program SPSS 20. Analisis yang dilakukan merupakan analisis univariat dan analisis bivariat, yaitu analisis chi-square.

\section{HASIL PENELITIAN}

Tabel 1 menunjukkan data umur kelompok kasus yang umumnya masuk dalam kelompok umur 20-25 tahun sedangkan Tabel 2 menunjukkan data umur kelompok kontrol yang umumnya masuk dalam kelompok umur 36-40 tahun.

Tabel 1. Data umur kelompok kasus

\begin{tabular}{cll}
\hline Kelompok Umur & $\mathrm{N}$ & $\%$ \\
\hline $20-25$ & 16 & 41 \\
$26-30$ & 9 & 23,1 \\
$31-35$ & 5 & 12,8 \\
$36-40$ & 9 & 23,1 \\
Total & 39 & 100 \\
\hline
\end{tabular}

Keterangan: $\mathrm{n}=$ jumlah sampel

Tabel 2. Data Umur Kelompok Kontrol

\begin{tabular}{lll}
\hline Kelompok Umur & $\mathrm{N}$ & $\%$ \\
\hline $20-25$ & 7 & 33,3 \\
$26-30$ & 3 & 14,3 \\
$31-35$ & 3 & 14,3 \\
$36-40$ & 8 & 38,1 \\
Total & 21 & 100 \\
\hline
\end{tabular}

Keterangan $: \mathrm{n}=$ jumlah sampel

Tabel 3 menunjukkan jumlah paritas 
kelompok kasus yang umumnya masuk dalam multigravida.

Tabel 3. Data Jumlah Paritas Kelompok Kasus

\begin{tabular}{lll}
\hline Jumlah Paritas & N & $\%$ \\
\hline Primigravida & 5 & 12,8 \\
Multigravida & 34 & 87,2 \\
Total & 39 & 100 \\
\hline
\end{tabular}

Keterangan: $\mathrm{n}=$ jumlah sampel

Tabel 4 menunjukkan jumlah paritas kelompok control yang umumnya masuk dalam multigravida.

Tabel 4. Data Jumlah Paritas Kelompok Kontrol

\begin{tabular}{lll}
\hline Jumlah Paritas & N & $\%$ \\
\hline Primigravida & 2 & 9,5 \\
Multigravida & 19 & 90,5 \\
Total & 21 & 100 \\
\hline
\end{tabular}

Keterangan: $\mathrm{n}=$ jumlah sampel

Tabel 5 menunjukkan data IMT kelompok kasus yang umumnya masuk dalam kelompok IMT 30-34,9 $\mathrm{kg} / \mathrm{m}^{2}$ (Obesitas I).

Tabel 5. Data Obesitas berdasarkan IMT Kelompok Kasus

\begin{tabular}{lll}
\hline IMT $\left(\mathrm{Kg} / \mathrm{m}^{2}\right)$ & $\mathrm{N}$ & $\%$ \\
\hline $30-34,9($ Obesitas I) & 26 & 66,7 \\
$35-39,9($ Obesitas II) & 13 & 33,3 \\
Total & 39 & 100 \\
\hline
\end{tabular}

Keterangan: $\mathrm{n}=$ jumlah sampel

Tabel 6 menunjukkan data IMT kelompok control yang umumnya masuk dalam kelompok IMT 35-39,9 kg/m (Obesitas II).

Tabel 6. Data Obesitas berdasarkan IMT Kelompok Kontrol

\begin{tabular}{lll}
\hline IMT $\left(\mathrm{Kg} / \mathrm{m}^{2}\right)$ & $\mathrm{N}$ & $\%$ \\
\hline $30-34,9($ Obesitas I) & 7 & 33,3 \\
35-39,9 (Obesitas II) & 14 & 66,7 \\
Total & 21 & 100 \\
\hline
\end{tabular}

Keterangan: $\mathrm{n}=$ jumlah sampel
Analisis chi-square dilakukan untuk melihat hubungan antara IMT ibu dan preeklampsia mendapatkan nilai signifikansi p 0,013 $(<0,05)$.

Tabel 7. Analisis hubungan Obesitas dan Preeklampsia

Jenis Obesitas Pre-Eklampsia Responden Tidak Ada Total P OR(95\%IK)

\begin{tabular}{lllllr}
\hline Obesitas I & 7 & 26 & 33 & 0,013 & 4,00 \\
Obesitas II & 14 & 13 & 27 & $(1,29-12,32)$ \\
Total & 21 & 39 & 60 & & \\
\hline
\end{tabular}

Keterangan: $\mathrm{n}=$ jumlah sampel

\section{BAHASAN}

Pada penelitian ini data berdasarkan umur didapatkan bahwa kurang dari setengah responden kelompok kasus berusia <25 tahun yaitu sebanyak 41\% sedangkan kelompok kontrol berusia $<40$ tahun sebanyak 38,1\%.

Data berdasarkan paritas kelompok kasus dan kelompok kontrol masingmasing didapatkan bahwa sebagian besar responden multigravida yaitu sebanyak 34 responden $(87,2 \%)$ dan19 pasien $(90,5 \%)$. Pada penelitian ini didapatkan lebih banyak multigravida. Hal ini karena sebagian besar responden berada pada kisaran umur 23 35 tahun dan umumnya ibu - ibu pada usia tersebut telah beberapa kali hamil dan melahirkan anak, sehingga didapatkan lebih banyak multigravida.

Data obesitas berdasarkan IMT pada kelompok kasus terutama tergolong dalam kelompok Obesitas I $\left(30-34,9 \mathrm{~kg} / \mathrm{m}^{2}\right)$ yaitu berjumlah 26 responden atau sekitar 66,7\% dari kedua subjek penelitian di kelompok kasus. Hasil ini sesuai dengan penelitian sebelumnya yang dilakukan oleh Roberta et al. ${ }^{17}$ yang mendapatkan subjek penelitian kelompok kasus masuk dalam kelompok obesitas. Data obesitas berdasarkan IMT pada kelompok kontrol menunjukkan bahwa 66,7\% masuk dalam kelompok Obesitas II (35-39,9 kg/m²).

Dari hasil perhitungan tabulasi silang didapatkan bahwa sebagian besar responden obesitas I mengalami pre- 
eklampsi yaitu sebanyak 26 pasien $(66,7 \%)$ dan sebagian kecil pasien obesitas II tanpa mengalami pre-eklampsia yaitu sebanyak 14 responden (33,3\%).

Hasil hitungan uji chi square dengan tingkat signifikan $\alpha=0,053$ menunjukkan nilai $\mathrm{p}=0,013(<\alpha=0,05)$ yang artinya terdapat hubungan Hasil penelitian ini sesuai dengan penelitian sebelumnya yang dilakukan oleh Mbah et al. ${ }^{18}$. Penelitian yang sebelumnya menunjukkan bahwa wanita hamil dengan obesitas memiliki risiko tiga kali lebih besar untuk mengalami preeklampsia dibandingkan dengan yang normal.

Terdapat beberapa keterbatasan dalam penelitian ini yaitu:

1. Kemungkinan bias. Pada penelitian ini tidak diperhitungkan kemungkinan kebiasaan pasien seperti merokok dengan pre-eklampsia,

2. Pada penelitian ini hanya dipakai status gizi wanita hamil pada akhir kehamilan berupa data tinggi badan dan berat badan untuk mengetahui IMT pada akhir kehamilan. Seharusnya digunakan pengukuran IMT pada awal kehamilan.

3. Data pasien dalam rekam medik banyak yang tidak lengkap khususnya data diagnosis pre-eklampsia yang menentukan pre-eklampsia berat dan ringan.

\section{SIMPULAN}

Berdasarkan hasil dan bahasan dapat disimpulkan bahwa terdapat hubungan obesitas pada kehamilan dengan preeklampsi dari pasien di RSUP Prof. Dr. R. D. Kandou Manado

\section{SARAN}

1. Untuk penelitian selanjutnya disarankan mengarah pada faktor-faktor yang memengaruhi terjadinya pre-eklampsia pada ibu hamil.

2. Diharapkan tenaga kesehatan dapat memberikan penyuluhan atau konseling kepada ibu hamil mengenai faktor resiko terjadinya pre-eklampsia pada ibu hamil.

3. Bagi ibu hamil hendaknya menjaga berat badannya selama hamil agar mengalami kenaikan secara normal

\section{DAFTAR PUSTAKA}

1. Roberts JM. August PA, Bakris G. Barton JR, Bernstein IM, Druzin M, et al. Hypertension in pregnancy. Washington: American College of Obstetricians and Gynecologist, 2013.

2. Young BC, Levine RJ, Karumanchi A. Pathogenesis of pre-eclampsia. Annu Rev Pathol Mech Dis. 2010;5:173-92

3. Cunningham $F$. Leveno $K$, Bloom $S$, Spong CY, Dashe J, editors. William Osbtetrics 24th ed). Philadelphia: McGraw-Hill, 2014.

4. Hladunewich M, Karumanchi A, Lafayatte R. Patophysiology of the clinical manifestation of preeclampsia. Clin J Am Soc Nephrol. 2007;2:543-9.

5. Miller DA. Hypertension in pregnancy. In: Cherney AH, Nathan L, Goodwin TM, Laufer N, Roman A, editors. Current diagnosis \& treatment obstetrics \& gynecology Edisi ke-11. Singapore: McGraw-Hill, 2013.

6. Bodnar L, Ness R, Harger G, dan Roberts J. Inflammation and triglycerides partially mediate the effect of prepregnancy body mass index on the risk of preeclampsia. American Journal of Epidemiology. 2005;162:1198-206

7. Hubungan paritas dan usia ibu dengan kejadian Pre-Eklampsia berat (PEB) [Internet]. 2012 [updated 2012 Feb diperbaharui 13 Februari 2012; dikutip 1 September 2012). Diunduh dari: http://www.ktiskripsi.net/2012/02/hubungan-paritasdan-usia-ibu-dengan.html.

8. Djannah SN, Arianti IS. Gambaran epidemiologi kejadian PreEklampsia/eklampsia di RSU PKU Muhammadiyah Yogyakarta tahun 2007-2009. Buletin Penelitian Sistem Kesehatan 2010;13(4):378-85

9. Obesity and overweight [homepage on the Internet]. 2012. Available from: http://www.who.int/media centre/factsheets/fs311/en/index.html.

10. Vahratian A. Prevalence of overweight and obesity among women of childbearing age: results from the 2002 National Survey of Family Growth. Matern Child Health J. 2009;13:268-273. 
11. Schulze M, Fung T, Manson J, Willett W, dan Hu F. Dietary patterns and changes in body weight in woman. Obesity. 2006;14:1444-53.

12. Ideal body weight (IBW) [homepage on the Internet]. 2006. Available from: http://www.medilexicon.com/medical dictionary.php.

13. Robert J, Bodnar L, Patrick T, dan Powers R. The role of obesity in preeclampsia. Pregnancy Hypertens. 2011;1(1):6-16.

14. Alanis M, Goodnight W, Hill E, Robinson C, Villers M, Johnson D. Maternal super-obesity (body mass index $\geq 50$ ) and adverse pregnancy outcomes. Acta Obstetricia et Gynecologica. 2010;89:924-30.

15. Madan J, Chen M, Goodman E, Davis J, dan Dammann O. Maternal obesity, gestational hypertension, and preterm deli-very. The Journal of Maternal-
Fetal and Neonatal Medicine. 2010;23(1):82-8.

16. Guelinckx I, Devliegers R, Beckers K, Vansant G. Maternal obesity: Pregnancy complication, gestational weight gain, and nutrition. The International Association for the Study of Obesity. Obesity reviews. 2008;9:140-60.

17. Ness R, Zhang J, Bass D, Klebanoff $M$. Interactions between smoking and weight in pregnancies complicated by preeclampsia and small-forgestational-age birth. American Journal of Epidemiology. 2008;168:427-33.

18. Mbah A, Kornosky J, Kristensen S, August E, Alio A, Marty P, et al. Super-obesity and risk for early and late pre-eclampsia. BOJG. 2010;117:997-1004. 